This item was submitted to Loughborough's Research Repository by the author.

Items in Figshare are protected by copyright, with all rights reserved, unless otherwise indicated.

\title{
Searching for injustice and finding solidarity? A contribution to mobilisation theory
}

PLEASE CITE THE PUBLISHED VERSION

http://dx.doi.org/10.1111/j.1468-2338.2008.00510.x

PUBLISHER

(c) Blackwell Publishing / ( ) The author

VERSION

AM (Accepted Manuscript)

LICENCE

CC BY-NC-ND 4.0

\section{REPOSITORY RECORD}

Atzeni, Maurizio. 2019. "Searching for Injustice and Finding Solidarity? A Contribution to Mobilisation Theory". figshare. https://hdl.handle.net/2134/3682. 
This item was submitted to Loughborough's Institutional Repository by the author and is made available under the following Creative Commons Licence conditions.

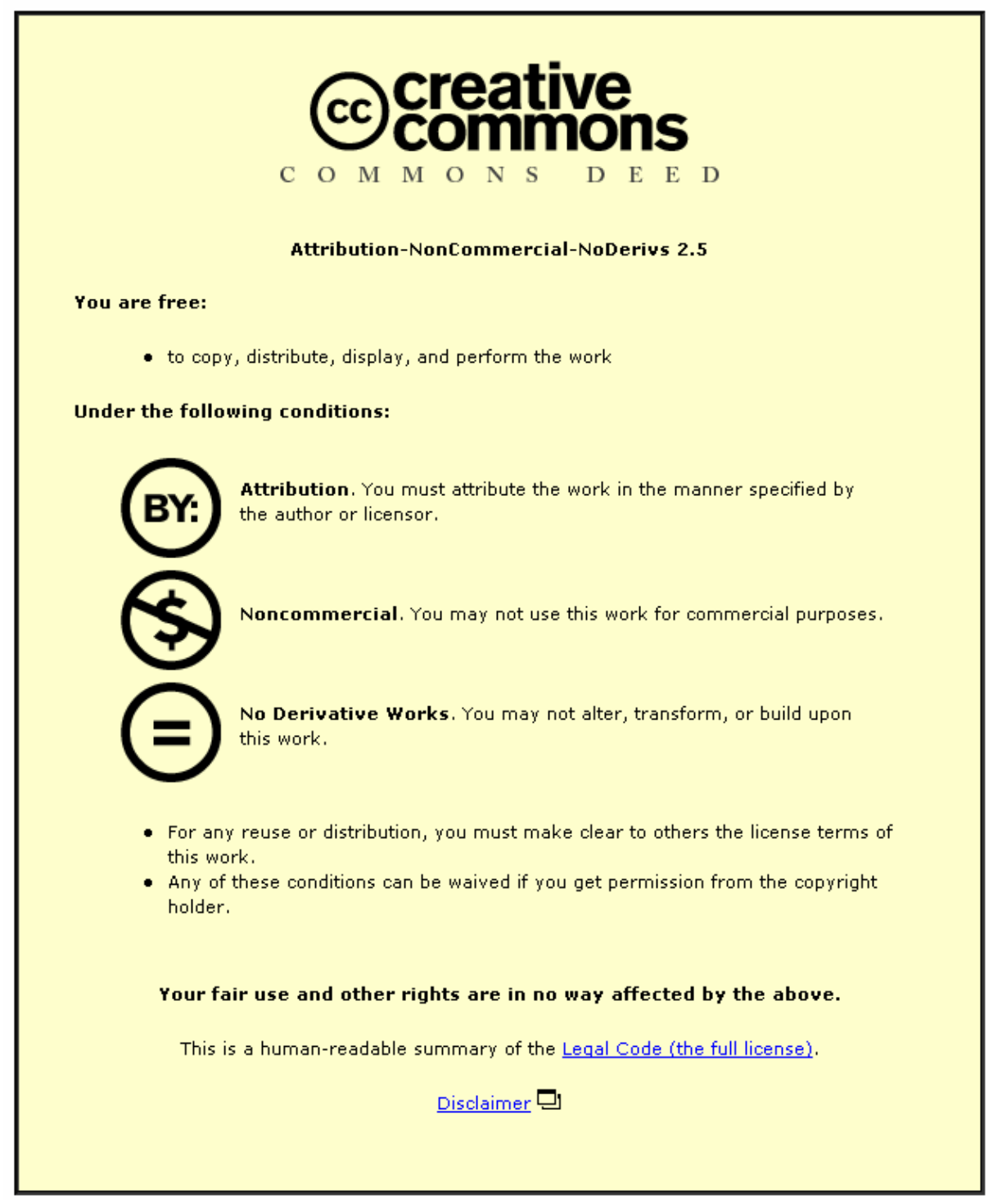

For the full text of this licence, please go to: http://creativecommons.org/licenses/by-nc-nd/2.5/ 


\title{
Searching for injustice and finding solidarity? A contribution to mobilisation theory.
}

Maurizio Atzeni (Contact the author at: M.Atzeni@lboro.ac.uk)

\begin{abstract}
:
This paper, using empirical data from cases of mobilisation in 1996 in Argentina, offers new evidence to build on the theory of mobilisation as recently proposed by Kelly. The use of injustice as the basis of mobilisation, raises some doubts for both its intrinsic subjective nature, and in the light of cases of spontaneous mobilisations. A re-formulation of the theory is suggested, less attached to a mechanical sequence and more rooted in the contradictions of the capitalist labour process.
\end{abstract}

\section{Introduction}

For those on the left interested in the study of labour, the publication in 1998 of John Kelly’s Rethinking industrial relations: mobilisation, collectivism and long waves, was finally some water in the desert of industrial relations. After years of sterile criticism of the practices of human resource management, Kelly's work was a return to the never forgotten centrality of workers' collective action and its potentiality within the context of capitalist labour relations.

Despite the relevance of the theory, in particular, for the study of industrial conflict and trade unions organising, Kelly's work has rarely been used to analyse concrete 
cases of mobilisation and it is known more as the, par excellence, Marxist radical reference in the pluralist dominated HRM, than as a useful framework for critical analysis. However, mobilisation theory inspired works have appeared, in relation to leadership (Darlington 2001, Green 2000, Metochi 2001), unions organising (Gall, 2003, 2000, Kelly and Badigannavar 2005) and injustice (Brown Johnson and Jarley, 2004). All of these have reached conclusions fundamentally compatible with the main assumptions of the theory.

According to the theory of mobilisation, workers have to pass through a certain number of psychological/organisational stages before a collective action can materialise. Central to this construction are individual perceptions of injustice (that something is "wrong" or "illegitimate", Kelly, 1998: 27) which are made explicit and framed by leaders attributing these to a specific agent. In this process and following this sequence, individual perceptions become collective sharing and thus opens, in the presence of a minimum level of organisational resources, the possibility for workers to take action collectively.

This research aims to engage constructively with these micro aspects of the theory and particularly with the use of injustice, testing Kelly’s model by reconstructing the dynamics of mobilisation in two cases that occurred in two car plants in Argentina, during 1996. 
Empirical material shows that mobilization theory does not account for all the cases of spontaneous, non-organised action ${ }^{1}$. Here, the model proposed by Kelly (injusticeleadership-action), is inverted with leaders and a sense of diffused injustice as ex post product of the mobilisation.

This fact has important theoretical implications that form part of the approach taken in this paper. Firstly, the paper denies the validity of injustice, in itself a subjective and individualistic concept, as the objective basis of mobilisation. Secondly, it places leaders as a product emerging from mobilisation rather than as a necessary precondition for mobilisation. Hence, cases of spontaneous collective action put into question the overall validity of Kelly’s model. It highlights Kelly’s model as a leader centred framework for action which may be useful for unions organising, but which is far less useful as a general theory of collective action.

Consequent with these theoretical assumptions and against a view of collective action as based on individual injustice, the overall aim of the paper is to reinsert mobilisation theory within the sphere of class action by rooting collectivism in the workplace solidarity created by the capitalist labour process.

This paper is organised as follows. The first section presents the main theoretical concerns with reference Kelly's use of the concept of injustice and invites a reconsideration of collectivism, in the light of the structuring of workplace relations. The second section focuses on the methodology used and introduces the cases considered. The third and fourth sections re-evaluate the concerns raised in the

\footnotetext{
${ }^{1}$ In the context of this paper, spontaneous and non-organised are used as synonymous. An ideal example of this type of action is Fantasia's case on 'the internal dynamics of wild-cat strikes', Fantasia 1988, ch.3.
} 
theoretical part in the light of the empirical evidence collected. In the last section some implications for further research and conclusions are discussed.

\section{Collectivism, injustice and solidarity}

According to Kelly, injustice is not just "the sine qua non of collective action" (Kelly 1998: 27). It "should form the core intellectual agenda for industrial relations" (Kelly 1998:126) and, “perceived injustice is the origin of workers' collective definition of interests" (Kelly 1998:64). Thus, it is crucial to ask: what is injustice and, should we consider it as adequate to frame workers' definitions of interests?

The concept of injustice, with its all encompassing and easy to grasp moral value, remind us more of the peaceful marches in defence of civil rights, than of the employment relationship. Despite the rhetoric of empowerment and job satisfaction, it is not a surprise that workers are often the victims of injustices produced by a system of power relations in which management right to manage is rarely questioned (Harley, 1999; Lewchuck and Robertson, 1997) . Their vulnerability to employer’s decisions on redundancies, wages, working time, productivity, discipline in the workplace, their dependence on capital to survive force them to accept compromises so reproducing the dominant system (Lebowitz 2004). Are they simply dissatisfied or do they feel the situation as unjust? How does each individual frame his/her sense of injustice? When, paraphrasing Barrington Moore (1978), do they move from a sense of inevitability of their conditions to a sense of inevitability of action? Who decides the moment in which tolerance and acceptance of the compromise with the system is no longer sustainable? 
The use of injustice as the basis of mobilisation is a mistake, especially if our frame of reference is that of the conflictual nature of the employment relationship. Once we support the view, as Kelly does, that workers and employers have conflicting different objective interests, depending on their respective position within the capitalist system, we cannot define interests in individual terms through the use of injustice. At the same time and for the same reason we cannot think of collective action as the sum of individual feelings but rather as "a communicative process within the association of workers, whose individual potential to sanction is minimal because of their atomization” (Offe and Wiesenthal 1980:79).

How can we think of a general theory of collective action based on a concept that is subjectively determined? How this can lead to a collectivist agenda? The overall impression, and this may explain Kelly's over-emphasis on injustice, is that mobilisation theory, while aiming to be a generally applicable theory, in reality is not more than a framework for action functional for unions organising.

Understanding how workers construct collective identities and interests is very complex and it is to Kelly's merit that he has attempted to create a broad, historical and system framed conceptualization of mobilisation. However, we maintain that to understand how workers' collectivism is created and sustained over time a different approach than the one based on injustice is required. We need to go back to the contradictions created by the structural nature of the capitalist labour process, a mode of production where work is never an individual process despite worker experience to the contrary. It is the appearance of individualism, given precedence over the reality 
of collective participation in the capitalist labour process, which often leads to confusion regarding cause and effect (Martinez Lucio and Stewart 1997:53).

The contradictions created by the capitalist mode of production produce crises both in the workplace and in society that give room to moments of collectivisation, those necessary processes through which the constant clashes between the manifestation of workers' individual and collective needs may be temporarily solved (Offe and Wiesenthal, 1980; Pizzorno, 1981). It is in this context that different patterns of collectivism, depending on the establishment of solidarities both within and outside the workplace, may be identified, eventually forming the building blocks for a more formal strategy of collectivism that can develop into a strategic expression of social and cultural resistance (Stephenson and Stewart 2001: 14). Thus, we can argue that workers' collective action on the one hand will always be based on a certain level of 'structured' solidarity, a product of the conflicting nature of the employment relationship in capitalist societies, and on the other hand will always be entangled within a complex structure of power relations within both the workplace and society.

By rooting the existence of collectivism and solidarity in these contradictions we are able to account for all those cases of spontaneous, unorganised mobilisations that the action of a leadership or a sense of injustice cannot explain. Further, we are not forced to look at mobilisation as necessarily based on the existence of empirically tested preconditions but rather as something in 'the making' (Fantasia 1988, 1995). At the same time, rooting mobilisation in the contradictions that the labour-capital relation constantly recreates is crucial in understanding variations in the historical and international level of labour unrest (Silver 2003). 
In conclusion we can say, especially in a militant/organising perspective, that emphasising the importance of moments of collectivism, the 'cultures of solidarity' these create, their linkages with the cultural and social milieu and their different patterns in the construction of collective action, is fundamental to give substance and consistency to any effort of mobilising workers. Focusing on these moments also helps to clearly identify all capital's counter-mobilizing attempts. Thus, far from offering a clear, fixed and linear way of thinking about collective action we should be able to express its complexity and dynamics.

Considering this theoretical background, the empirical material has been organised with two aims in mind: a) to show that mobilization can occur for reasons not directly depending on individuals' senses of injustice or leaders persuasive action and b) to provide a map of the developments and involutions in the process of collectivisation and solidarity formation.

\section{Methodology}

This paper is based on fieldwork conducted in the city of Córdoba, Argentina, in 2002/2003 on two factory occupations that occurred in 1996 in the FIAT and Renault car plants. The events investigated were very specific. Not all the workers necessarily participated in the mobilisations or in all the phases of these. Thus, instead of selecting the interviewees using a random sample, a method of systematic diversification has been adopted (generations, working position, union's affiliation) in both cases. At the same time, interviewees were selected having in mind their level of participation in the conflict so to form four main opinion groups: managers, less 
militant workers (often workers still employed by the companies), the more militant (activists) and the heterogeneous. Sixty qualitative in-depth and semi-structured interviews were collected in total.

There were six years gap between the events and the research and often workers that participated in the mobilisations were difficult to find as they were employed in other sectors and/or did not want to talk. However this has not created problems but rather advantages in terms of methodology. The time gap, forcing people to remember, has in fact favoured a more clear and focused reconstruction of the events.

The aim of the fieldwork was to get primary data on concrete events of mobilisation and, analysing their dynamics, compare this with the model offered by the theory of mobilisation. This, in particular, meant a search for injustice, this being, according to Kelly, the conditio sine qua non for mobilisation. In this process I found so many different types of injustice. This suggested the need to look for a different, structurally rooted, basis of collective action.

Following the aims of the research, the dialogue with the interviewees went through the following issues: workers and their relations with the employer, workers and the socio-political environment, workers and the union, workers, leadership and activism, workers and the dynamics of mobilisation, managers and the dynamics of mobilisation.

In addition, the validity of the data has been strengthened also by the use of documentary data. For the case of FIAT, the company's internal reports, security 
videos and press conferences have offered a different point of view of the event and more clarity on the strategy pursued by management during mobilisation and counter mobilisation. Archives of the local newspaper and of the university's television channel have also been scanned for items at the time of conflict.

\section{The research context}

During the 1990s, Argentina was considered as one of the most virtuous examples in the implementation of the so called structural adjustments, inspired by the dominant neo-liberal visions of economy promoted by international financial institutions. The fictitious parity between peso and dollar benefited foreign investment but depressed local business and produced unemployment. Public companies were privatised and thousands of workers made redundant in this process (Thwaites Rey, 1999). Reforms inspired by the flexible use of labour were introduced in the labour law (Battistini and Montes Cato', 2000). The consequences of these destabilising policies produced a consistent, although disorganised, number of struggles at local and national level against both the employer and, often, collaborationist trade unions.

Trade unions in Argentina, because of their fundamental role as mass organisers and political support for the Peronist movement, have a very high level of politicisation. They have a vertical structure with centralised power (financial and political) and personified by a leader who is, most of the time, politically tied to the leadership of the Partido Justicialista (the party form of the Peronist movement). This particular relation with political power made trade unions' action extremely contradictory, especially when they had to support government's decisions openly against the people 
they were supposed to represent (Martuccelli and Svampa, 1997). This is what happened during the double presidency of Menem in the 1990s. Trapped between the loyalty to a Peronist president, whose reforms were eroding workers' rights, and a growing grassroots movement, trade unions were successful in the control of mobilisations (like in the case of Renault) or were bypassed by workers' spontaneous action (like in the case of FIAT).

As a consequence of the politicisation of the majority of the Argentinean trade unions (to have the power of legally representing its members, a trade union needs an official authorisation granted by the Ministry of Labour), workers have often mobilised outside the union channel as a reaction against both the employer and the trade union. This, together with companies' approach to conflict, is fundamental to identify differences between the two cases of mobilisation.

In 1996 FIAT was in the process of upgrading its engine with a new assembly plant. This decision to increase its investment in Argentina was creating expectations among the workers in the engine factory. These were people with apathy in relation to conflict, fully engaged by the company's paternalism, with a high level of income, especially compared with the rest of workers in the country, with expectations of growth in their careers within the company and in society as well. The objective reality they were facing before the conflict was that of security and stability.

Mobilisation exploded unexpectedly when management decided, all of a sudden, to force workers to sign a new flexible contract with a drastic salary reduction. As a consequence, workers occupied the factory out of trade union control and without any 
recognised leaders. The same people that for years had maintained themselves in the comforts of the island of welfare their employment could offer changed with the new conditions they had to face. The situation and the action that followed it forged the process through which compañerismo (a fair relation with their fellows workers in the same line) became active solidarity. This produced a radicalisation of conflict and the establishment of a permanent state of open confrontation and adversarial relations between management and new, democratically elected, workers' representative.

In the case of Renault as well workers had to face the implementation of a set of “flexible” measures that negatively affected their previous working and salary conditions. But while in the case of FIAT these changes were introduced abruptly and unleashed strong mobilisation out of union and company control, in the case of Renault, workers experienced a prolonged deterioration of their conditions. The workforce was reduced selectively and with the use of incentive schemes. Entire sections were outsourced to external companies with new employment conditions for those workers that could maintain their posts. In a few years, Renault in complicity with the business union SMATA, effectively introduced all the organisational changes necessary to make the company more profitable. This strategy helped to keep conflict under control. Workers did mobilise to occupy the plant, and genuinely supported an oppositional and more militant stance within the union, but the divisions among them provoked by company strategy and the unsuccessful attempt to win control of the union, broke solidarity and any possibility of conflict radicalisation.

Summarising, if we want to establish differences between the two cases we could consider companies' strategy and trade unions' control of mobilisations as those 
factors whose material presence or absence has hampered or facilitated mobilisation. However, the identification of these causes may explain the specific cases analysed but this is not necessarily true in all the cases.

What has more theoretical consequences is that at FIAT the contemporary absence of a clear company strategy and a trade union control of workers' reactions to the introduction of the new contract produced a vacuum of power. In this context, momentarily free of obstacles, workers reframed their process of mobilisation in and through the struggle. The case of FIAT is the one that, by inverting Kelly's model of mobilisation, ask us to search for an alternative model.

\section{Findings:}

\section{a) Workers' injustices}

FIAT's workers occupied their factory unexpectedly, after more than 20 years of passivity, forced to this by a drastic reduction of salaries imposed unilaterally by the company. The conflict changed the lives of many and their unconditional identification with the company.

"We were all wearing the FIAT shirt. When I was ordered: "do this or do that", I have always executed the order, I have always complied with the obligations of my work. We were very happy with the situation we were living and we were interested in the productivity of the plant." (FIAT worker 31). 
After they signed to the new, pejorative, contract and in the nightly discussions with their families, workers were trying to define their sensations and to give an explanation of the situation in which they were living:

"the change of contract broke an entire life project, it destroyed myself and my family, I could not accept that idea" (workers' delegate), "you were feeling as though someone had robbed you, it is like when you buy a toy for a kid and when you are going to give him, and the kid with all the hope to play, you tell him "it was not for you it was for someone else” (workers' delegate). "In that plant people always worked a lot, production rhythms were very high. People worked a lot but they were proud to be employed by that company. The company did not recognise this and people felt betrayed, injured” (FIAT mobilisation leader).

Workers felt hit for many reasons: because they were working more and earning less, because they felt betrayed by the company, because a life project was at risk, because their "island" of welfare was submerged by the "sea" of unemployment and flexibility surrounding their plant. Each worker had his/her own reasons to feel the situation as unjust. Renault's workers in the meantime were not mobilising but were suffering suspensions, selective lay offs and intensification of work. Did they feel all this as unjust? Consider the following quotations:

"we were all aware, all.....unfortunately how many "broncas" (anger, regrets, sorrow) we had to accept? Thousands and thousands of "broncas". You have to hold out and accept it for the family, you have to tolerate many things" (Renault worker 12). "You were surrounded with no possibility to move, you had to stay in the middle. 
Everybody felt fear, fear to lose the job, fear of the government, fear of the enterprise, fear of the union. Fear, fear, fear" (Renault worker 1).

At this stage of analysis, despite the evidence that before mobilisation workers may have individually felt a sense of injustice (although for not coincident reasons and this confirms how different and eventually conflicting may be workers' interests once considered from an individual point of view), collectively they did not share it yet.

The problems in considering injustice as the basis of mobilisation appeared again while interviewing people who, six years after the conflict and despite economic crises, were still working in the FIAT plant and who experienced those moments of mobilisation. These kinds of people maintained the strongest affective relation with the company. In their view, there was no injustice in the decision to cut their salaries. Nobody was of course happy about the changed situation but individually they came to accept and justify the new labour conditions.

"You have to be realist and always stay on the side of the enterprise. You have to be fully aware that an enterprise pays a salary for the work that a person does and you have to agree with that working condition. I have always been on that side, if I do not like it I do not stay. But if in that moment I was staying behind a machine, doing the same and earning less than before, I could not tell you what I could have done" (FIAT manager personnel office, former production worker).

Others stressed the view that their sacrifice was justified by the fact that young workers were now entering the plant and that was an important social development 
for the entire community. The majority of them accepted because of the responsibility they had for the family

"I have a family, I cannot say "well I give up the job" if there is no other option. (FIAT worker 1).

Generally it appeared that working in the plant was somehow addictive for those people who had already spent a number of years in the factory, which applied both to FIAT and Renault workers. The production rhythms, a certain stability and social recognition achieved during the years, the repetitiveness of a life structured around the plant, the development of inflexible skills adapted specifically to the production of parts of cars, created in many people, including those who initially mobilised, a sort of dependency on the factory.

"The point is that those people that have passed, in practice, a life inside the factory maybe do not see things as one who has thought to leave the factory. A person that lived inside there, when he goes from the plant to the street looking for a job, does not even know how to sell something. He structured his life working there and if you send him to the corner to sell a "Mantecol", (popular biscuit frequently sold in street kiosks) he does not know how to do it” (workers'delegate).

Although individually workers may perceive a specific situation as unjust, their sense of injustice and their possible reactions tend to remain blocked between structural constraints (they simply need to maintain the job because no alternative options are offered, because of the responsibilities of the family, and because of the non 
adaptability to a working life outside the factory) and the impossibility of identifying a collective agent.

The day of the factory occupation, which also corresponded to the beginning of mobilisation, workers were of course feeling uncomfortable with the unexpected decision of the company to change their contract but they did not know what to do. The union delegates disappeared. For the company a normal day of work was starting. There were no recognised leaders, there was no organisation, and nobody knew what to do. People started to work but only for a few hours.

"The day after we entered the plant and we found a very strange situation, a very strange atmosphere. People meeting together in all the corners, everybody was meeting, it was like the day could not start. We reached the changing room but we did not even change. "A mate is saying that we have to gather". And it was something instantaneous. We went forward to the small square in front of the plant, none of the union delegates was there, "this is not what they had told us... somebody that could explain... let's go to ask for explanations, let's go and demand some explanations”. And people went out of the plant in order, I think everybody was there and they went walking forward, “What is happening?” (FIAT worker, Quality Control Department).

'A debate started, in the whole plant there were discussions. After this a movement started to grow, they started to mobilise. They had no idea of where to go and what to do but nonetheless they started to gather, they were many, and then an internal mobilisation of the plant, without leaders, started to emerge' (FIAT Industrial Relations Director). 
'The day after they reached the plant feeling bad, a collective bad feeling and without anybody suggesting anything to them, they got together. What should we do?' (FIAT mobilisation leader).

The factory occupation was spontaneous, unplanned, not organised. FIAT workers were not used to mobilisation and in the previous years they had just participated in a few national strikes because they were under pressure from the union that was formally representing them. People were used to solving working problems directly with the foreman and individually each of them had already accepted the conditions of the new contract. Even if the majority did not like it, nonetheless they had to accept it. It is just when they met again at work that mobilisation started and with it their perceptions of injustice became explicit. Workers started to talk, became conscious of what was happening, solidarity emerged within the workplace, natural leaders unified individual sensations. From individual rebellion and discussions among groups of workers the wave grew and people occupied the plant not knowing what they were doing apart from the fact that they needed to understand what was happening. Somebody violently closed the factory gate and the mobilisation became an occupation.

Summarising from this empirical evidence, injustice is not just subjective and thus difficult to theorise. It also tends to be framed by the action itself rather than constituting the conditio sine qua non of mobilisation. Workers become conscious of how "unjust" a certain situation is once action has already started, once collectively they can share and strengthen the same perceptions. This is a founding moment of 
mobilisation because it gives concrete collective meaning to what was previously a set of individual perceptions of injustice. There are no mechanical, predetermined movements from injustice to mobilisation but it is the status of mobilisation, the action in itself, that allows a "conscious” injustice and consequently an operative and cohesive function of it within the whole process of mobilisation. This does not necessarily mean that without collective action injustice does not exist at all. The feeling can be to different degrees perceived but is dominated by the acceptance of the inevitable and the actor has already processed the changed situation and has accepted it, willingly or not. Thus workers may individually perceive injustice but their mobilisation will always remain a mere possibility if there is no space left for moments of collectivisation where solidarity can be activated.

These conclusions may depict a situation common to other cases of spontaneous mobilisations or instead represent just one of the possible outcomes. More research is certainly needed. Yet if we think of more "traditional" cases of leaders promoting mobilisation, for which more consistent research is available, we cannot avoid considering these are based on the same principle. Leaders will not be able to activate and sustain a mobilisation without a reframing of workers' interests in collective terms. Thus they will need to create and defend the space for reciprocal support and solidarity.

\section{b) The process of collectivisation and solidarity formation}

Following our theoretical position, the contradictions produced by the capitalist labour process often in combination with a favourable political and cultural climate, 
creates the room for moments of collectivisation, largely based on solidarity. Thus is this section we aim to provide an empirical mapping of the process of solidarity formation.

In the case of FIAT we have a heterogeneous group of workers that in the 20 years before the conflict never had a confrontation with the enterprise, were proud of the quality of their work, were totally identified with the company, were part of the workers' aristocracy, already had a place in the society and future plans of social and professional ascent:

"People were not so much concerned with solidarity......nobody wanted to lose anything because we had, compared with workers nationally, a good salary and a comfortable position... but we were losing what was in our common interests" (FIAT worker quality department).

Before the conflict there was compañerismo among workers. As people working in the same environment they considered themselves as colleagues. There was a natural empathy among them reinforced by the common sharing of social activities related to the work in the plant (football tournaments, social events organised by the company for the workers' families).

"at that time everything was quiet, we were earning very well and the rest was not important. Among us there was compañerismo, there were always parties, there were always people for this but not for the struggle” (FIAT activist 4). 
In the plant it was difficult to organise even a small protest for better food in the cafeteria and solidarity was not emerging because workers had no important complaints with the company, thus no interest in raising conflict.

"there was high production, we had to work extra time, the company needed workers because it was a high peak moment in the automotive production in Argentina. There was no pressure from the company, they rather always tried to respect the rules of the collective agreement that we had at that time” (FIAT activist 1)

But as a consequence of the events that led to mobilisation, compañerismo transformed itself into solidarity:

"there was compañerismo and nothing else. That is why the day of the factory occupation people were crying........ It was a situation for crying because...... solidarity, everything was unexpected, it was like something was set free, was released and this was positive for the people” (FIAT mobilisation leader).

Solidarity was released, was set free and workers grouped together as an almost instinctive reaction to the drastic change of contract:

"we went directly to clash and it wasn't, they forced you because a different solution was not available, they forced you to give that clash. They made it (the change of contract) so compulsive and the salary reduction so drastic that it resulted in a very strong blow and you had to replay it with another strong stroke, no alternative was left" (FIAT worker 32) 
Solidarity was emerging spontaneously even among a group of persons not used to conflict because there was no basis any more to support individualism. The paternalistic style used for decades by the company to control the labour force, the "golden splendour" of the isolation from the rest of the working class, bureaucratic unionism, all disappeared from one day to the other. In this new situation, without those elements that had maintained workers out of conflict for decades, new rooms for collectivization were created and solidarity became the basis of workers' strength. In that moment people started to achieve a deeper consciousness of their position within the more general social unrest of the country and this contributed to the radicalisation of their fight.

The issue of solidarity most explicitly appeared in the interviews with FIAT workers. If in this latter case they have experienced a sort of "progressive”, "increasing” sense in the strength of their solidarity, Renault workers have, by contrast, experienced a "regression" and their accounts appear full of scepticism. Both the company and the bureaucratic union contributed to this:

"The politics of the enterprise has always been to divide us if they suspected that we could gather and build solidarity among us. They tried to create conflict and divisions among us........ tell you once again, the one who loses is always the worker, I do not know if because of our lack of activity or because of their plan” (Renault worker 8).

"Many people say that in reality the union and the company arrange things among themselves but then say to people different things. It seems that it is like this because 
we didn't gain anything. We were feeling impotent and we couldn't even look for a different solution, with different people representing us because the union didn't allow us to do it” (Renault Worker 7).

"the company contributes to breaking the solidarity, I think. This was or it is what the company normally does, to break the unity among colleagues, we lived all this down there, I'm sure” (Renault worker 4).

Despite attempts to build an internal opposition to challenge both the bureaucratic union leadership and the strategy of the company, solidarity could not find room for its development, former opposition delegates were co-opted to the union apparatus and the process of outsourcing and de-localisation of entire company departments negated any possibility of future mobilisations.

By favouring an approach to solidarity as the active, dynamic component of each process of collectivisation we can explain those cases, like the one at FIAT, in which despite the non existence of favourable preconditions (for instance class consciousness, previous organisation) this was not an obstacle for people to mobilise. The case of Renault is the mirror of that of FIAT in the sense of reflecting the same but inverted image. In the first case the sudden mobilisation provoked a simultaneous collapse of the factors (company's paternalism, a diffused individualism, a bureaucratic form of unionism) that for years constrained the development of active solidarity. In the second case the same factors maintained the status quo thus hampering any attempt to build collective action. 


\section{Conclusions}

The working class did not rise like the sun at an appointed time. It was present at its own making (E.P.Thompson 1980:8).

A radical labour account of collectivism needs a certain level of abstraction and rejects empiricist obsessions if it aims to avoid both the tautology of contingent views of collective action (that workers mobilise in different ways under different conditions) and the morality and individualisation attached to the concept of injustice. The logic inspiring this paper has been to look at collective action as rooted in the contradictions and crisis generated by the capitalist labour process. These are the moments in which a taken for granted system and set of values (for instance management's right to manage, authority relations, bureaucratic control) is contested and new spaces are created for workers' interests' collectivisation. These are also the moments that show how the participative and collective nature of work can generate solidarity which in turn becomes central to attempts to organise workers.

Based on this theoretical starting point, first the inconsistency of injustice and then the process of collectivisation and solidarity formation have been empirically proven, always trying to offer an image of movement, of social processes in the making. The adoption of this methodological approach is crucial to explain the complex dynamics of processes of collectivisation. At the same time it is the best antidote to any empirically obsessed reconstruction of social reality. 
By criticising the subjective nature of injustice and stressing the importance of labour process generated solidarity, this article has contributed to a conceptualisation of mobilisation as fully inserted in the sphere of class action. Kelly's contribution remains very important as it is certainly a useful tool for trade unions' and leaders' action. However a more structurally grounded conceptualisation is needed. This paper has tried to engage with it and in doing so it may have reinforced Kelly's overall vision of the theory as framed by a Marxist logic of society and economy.

\section{References:}


Atzeni, M. (2005). Mobilisation theory, workers' solidarity and the evolution of conflict: collective action in multinational companies in Argentina. Doctoral thesis. University of Warwick.

Battistini, O. and Montes Cató, J. (2000). Flexibilización laboral en Argentina, un camino hacia la precarización y la desocupación. Revista Venezolana de Gerencia, 5/10: 63-89.

Brown Johnson, N. and Jarley, P. (2004). Justice and union participation: an extension and test of mobilisation theory. British Journal of Industrial Relations, 42: 543-562.

Darlington, R. (2001). Union militancy and left-wing leadership on London Underground. Industrial Relations Journal, 32: 2-21.

Fantasia, R. (1995). From class consciousness to culture, action and social organisation. Annual Review of Sociology, 21: 269-287.

Fantasia, R. (1988). Cultures of Solidarity: consciousness, action and contemporary American Workers. Berkeley: University of California Press.

Gall, G. (2002). Union organising: Campaigning for Trade Unions Recognition, London: Routledge. 
Green, A.M., Black, J. and Ackers, P. (2000). The union makes us strong? A study of the dynamics of workplace union leadership at two UK manufacturing plants. British Journal of Industrial Relations, 38: 75-93.

Gouldner, A. (1954). Wildcat strike. New York: Harper and Row.

Harley, B. (1999). The myth of empowerment: work organisation, hierarchy and employee autonomy in contemporary Australian workplaces. Work, employment and society, 13: 4-66.

Heery, E. (2002). Partnership versus organising: alternative futures for British trade unionism. Industrial Relations Journal, 33: 20-35.

Hyman, R. (1975). Industrial Relations, a Marxist introduction. London: Macmillan.

Kelly, J. (1998). Rethinking Industrial Relations: mobilisation, collectivism and long waves. London: LSE/Routledge.

Lane, T. and Roberts, K. (1971). Strike at Pilkington. London:Fontana.

Lebowitz, M. (2004). What keeps capitalism going?, Monthly Review 56/2, http://www.monthlyreview.org/0604lebowitz.htm 
Lewchuk, W. and Robertson, D. (1997). Production without empowerment: work reorganisation from the perspective of motor vehicle workers. Capital and Class, 63: 37-64.

Martuccelli, D. and Svampa, M. (1997). La plaza vacía: las transformaciones del peronismo. Losada: Buenos Aires.

Martinez Lucio, M. and Stewart, P. (1997). The paradox of contemporary labour process theory: the rediscovery of labour and the disappearance of collectivism. Capital and Class, 62: 49-77.

Metochi, M. (2002). The influence of leadership and member attitudes in understanding the nature of union participation. British Journal of Industrial Relations, 40: 87-111.

Offe, C. and Wiesenthal, H. (1980). Two logics of collective action: theoretical notes on social class and organisational form. Political Power and Social Theory, 1: 67-115.

Pizzorno, A. (1981). Interests and parties in pluralism. In S. Berger (1981) Organising interests in Western Europe. New York: Cambridge University Press.

Silver, B. (2003). Forces of labor, workers' movements and globalisation since 1870. Cambridge: Cambridge University Press. 
Stephenson, C. and Stewart, P. (2001). The whispering shadow: collectivism and individualism at Ikeda-Hoover and Nissan UK, Sociological Research Online, 6:3. http://www.socresonline.org.uk/6/3/stephenson.html

Thompson, E.P. (1980). The making of the English working class. London: Penguin.

Thwaites Rey, M. (1999). Ajuste estructural y privatizaciones en la Argentina de los '90 (O como achicar el estado no es agrandar la nacion). Doctoral thesis. University of Buenos Aires. 